\title{
O projekcie „po kapitalizmie”
}

Wyobraźmy sobie obszar, w obrębie którego do pewnej populacji dociera, że gromadzenie kapitału bez końca nie jest ani możliwe, ani pożądane, i w związku z tym wierzy ona, że inny świat nie tylko jest, ale musi być możliwy. W jaki sposób taka zbiorowość powinna wkroczyć na drogę ku innym rozwiązaniom? (...) Oczywiście, że to utopijne! Ale co z tego! Na nic innego nas nie stać.

David Harvey, Enigma kapitatu i kryzysy kapitalizmu

Projekt „po kapitalizmie” (www.pokapitalizmie.blogspot.com) realizowany był w Galerii Sztuki Współczesnej w Krakowie od marca 2012 r. do października 2013 r. Zasadnicza jego idea zrodziła się podczas jednego z moich spotkań z Anną Bargiel i Cecylią Malik. Dotyczyło ono nowej przestrzeni, jaka powstała w naszej instytucji. Formułowane przez nas w toku dyskusji kolejne pomysły dotyczące jej zagospodarowania odrzucałyśmy z powodu braku wystarczających środków finansowych do ich realizacji. Doszłyśmy zatem do wniosku, że należałoby stworzyć projekt na temat samej sytuacji braku pieniędzy na realizację projektów. I tak, wychodząc od szczegółowych rozważań, doszłyśmy do wizji działania mającego na celu ogólną refleksję nad kapitalizmem - generującym finansowe trudności systemem, w którym przyszło nam funkcjonować. Chodziło o zastanowienie się nad ewentualnymi możliwościami udoskonalenia tego systemu, bądź też zastąpienia go 
innym. Towarzyszyło nam przekonanie, że taka instytucja, jak Bunkier Sztuki powinna reagować na zmiany zachodzące w jej otoczeniu, odnosić się do aktualnych problemów społeczno-politycznych, a także eksperymentować z nowymi formatami pracy z publicznością. Szalone pomysły realizowania całego przedsięwzięcia metodą handlu wymiennego (np. udzielanie korepetycji przez pracowników Bunkra w zamian za świadczenia na rzecz projektu, czy też płacenie za wykłady wyłącznie artykułami pierwszej potrzeby pozyskanymi od sponsorów) dość szybko zostały porzucone jako nierealne, a także niepotrzebne - pewne, choć bardzo skromne środki finansowe jednak się znalazły. Ważną inspiracją dla projektu były teksty Davida Harveya, a w szczególności jego książka The Enigma of Capital and the Crises of Capitalism. Od początku całe przedsięwzięcie było realizowane we współpracy z Nowym Obywatelem, Nowymi Peryferiami i Stowarzyszeniem Doxotronica. Z osobami związanymi z tymi organizacjami konsultowałam tematykę projektu, przygotowywałam też niektóre wydarzenia. Ponadto wspieraliśmy się wzajemnie w zakresie promocji naszych działań. Tematykę całego przedsięwzięcia podzieliłam na cztery powiązane moduły: „miasto”, „teoria”, „sztuka” i „życie codzienne”.

Moduł „miasto” obejmował spotkania gromadzące zarówno aktywistów miejskich, jak i artystów zainteresowanych działaniami w przestrzeni publicznej. Ich celem było wsparcie krytycznej refleksji na temat przestrzeni Krakowa, między innymi w kontekście wpływu kapitalizmu na jej zmieniający się kształt (przykładem mogą być procesy gentryfikacyjne). Moduł ten od początku tworzyliśmy w konsultacjach z krakowskimi inicjatywami poświęconymi kształtowaniu przestrzeni miejskiej i kierującymi się ideą „prawa do miasta”. W jego ramach odbyły się spotkania na temat walki o Zakrzówek, komunikacji rowerowej i wizji ulicy Dietla jako bulwaru, wykład Andreasa Billerta na temat rewitalizacji, a także konferencja poświęcona rzekom w mieście. We współpracy z pracownią k. stworzyliśmy przed Bunkrem Sztuki miejski ogródek, a sama pracownia zaprezentowała rezultaty działań założonej przez siebie Akademii Alternatywnej Architektury Krajobrazu. Ponadto udzieliliśmy wsparcia Inicjatywie Prawo do Miasta (której miasteczko, legalnie umieszczone na Rynku Głównym w Krakowie, zostało z niego po pewnym czasie usunięte) w zakresie umieszczenia na placu przed budynkiem Bunkra Sztuki namiotu z biblioteczką książek na temat partycypacji i budżetu partycypacyjnego. We współpracy z projektem Nowa Krupnicza zorganizowaliśmy otwarte konsultacje społeczne na temat zmiany charakteru ulicy Krupniczej w Krakowie. Temat partycypacji społecznej w kształtowaniu przestrzeni miasta był 
następnie kontynuowany w ramach przygotowanej z Politechniką Krakowską wystawy i dyskusji poświęconym niezagospodarowanemu fragmentowi ulicy Karmelickiej w Krakowie.

Moduł teoretyczny obejmował kółko samokształceniowe, w ramach którego wygłaszano referaty na tematy związane z projektem oraz dyskutowano o książce Michaela Hardta i Antonio Negri Rzecz-pospolita przy wsparciu znawców tej problematyki (między innymi Ewy Majewskiej i Jana Sowy). Z inicjatywy Uniwersytetu Jagiellońskiego gościliśmy ponadto debatę z udziałem Roberto Esposito i Tadeusza Sławka. W dniach 7-8 grudnia 2012 roku zorganizowaliśmy natomiast konferencję „po kapitalizmie. od egoizmu do wspólnoty” (z której część referatów została opublikowana w tym numerze „Praktyki Teoretycznej”). W skład komitetu organizacyjnego weszli poza mną: dr Katarzyna Guczalska (Uniwersytet Ekonomiczny w Krakowie), dr Krzysztof Posłajko (Nowe Peryferie, Uniwersytet Jagielloński), Michał Pospiszyl (Praktyka Teoretyczna), dr Paulina Szkudlarek, Krzysztof Wołodźko (Nowy Obywatel), Michał Zabdyr-Jamróz (Doxotronica, Uniwersytet Jagielloński) oraz Tomasz Leśniak (Krytyka Polityczna). Wygłoszono 31 referatów, a gościnie wystąpił (na Skype) dr Krzysztof Nawratek. Ponadto odbyła się projekcja filmu Isabelle Fremeaux i Johna Jordana „Paths Through Utopia” oraz koncert Krakowskiego Chóru Rewolucyjnego. Konferencję zakończyło przygotowane przez Romana Dziadkiewicza wraz z przyjaciółmi całonocne wydarzenie performatywne „orgia na koniec świata (jaki znamy)".

Moduł „życie codzienne” poświęcony był działaniom antykonsumpcyjnym, względnie promującym świadomą konsumpcję. Odbyły się między innymi warsztaty recyklingowe, zorganizowane we współpracy z Małym Klubem Bunkra Sztuki, oraz - dzięki wsparciu Katarzyny Lorenc i stowarzyszenia MitOst - wakacyjny cykl ,życie codzienne po kapitalizmie", w ramach którego zajmowaliśmy się między innymi bankami czasu, spółdzielniami i ekologicznym dizajnem. W 2013 roku odbyła się z kolei seria wydarzeń Fanaberie Fashionfever Ferformance, których tematyka sytuowała się na styku sztuki i mody. Festiwal objął instalację i warsztaty w Bunkrze Sztuki, a także performansy w przestrzeni miejskiej. Jego celem było wskazanie na możliwość partycypacyjnych procesów produkcji ubrań.

W ramach modułu „sztuka”, we współpracy z projektem Sól, wspierającym drobne zakłady usługowo-handlowe w Krakowie, zorganizowałam między innymi akcję Szymona Kobylarza w obronie jednej z krakowskich cukierni. Umieszczenie w jej witrynie obiektu, który stworzył artysta, było nie tylko próbą przepracowania historii miej- 
sca, ale miało też pomóc w popularyzacji tematu przemian przestrzeni miejskiej (znikanie tradycyjnych zakładów rzemieślniczych) i promocji cukierni. W wakacje 2013 roku podjęłam współpracę z efemeryczną galerią Zbiornik Kultury. Wraz z kierującymi nią Mateuszem Okońskim oraz grupą Spirala zorganizowaliśmy liczne wystawy (nie tylko w Bunkrze Sztuki, ale i klubie Bomba, w specjalnie zbudowanym tam „white cubie”), spotkania, pokazy filmów, audycje radiowe i bazary. Wydaliśmy również serię zinów, a także udostępniliśmy teren przed galerią czytelni Krytyki Politycznej. Całość została doceniona przez lokalną redakcję „Gazety Wyborczej”, która przyznała Zbiornikowi nagrodę „Kulturalne Odloty” w kategorii „Miejsce Roku”. Warto podkreślić, że współpraca ze Zbiornikiem Kultury była de facto oddaniem części przestrzeni Bunkra Sztuki pod opiekę zewnętrznego kolektywu osób nastąpiła zatem czasowa i częściowa demokratyzacja przestrzeni galerii. Działania Zbiornika udało się przedłużyć za sprawą cyklu wirtualnych wystaw sztuki wideo Wirtualny Zbiornik Kultury. Zachęcaliśmy naszą publiczność do częściowego uniezależnienia się od galerii poprzez organizację prywatnych, domowych wernisaży przy użyciu wypożyczanego przez nas rzutnika. Każda wystawa składała się z filmu, w którym kuratorka przedstawiała jej koncepcję oraz listy linków, pod którymi kryły się prace video.

Warto podkreślić, że projekt „po kapitalizmie” wpisał się w szereg wielu eksperymentalnych działań Bunkra Sztuki tworzonych w odpowiedzi na współczesną sytuację społeczno-ekonomiczną, między innymi projekt „Wymiary Utopii” jak i aktywistyczne wystawy Łukasza Surowca i Cecylii Malik.

W powyższym tekście wykorzystałam fragment tekstu napisanego przeze mnie do wydanej przez Muzeum Sztuki w Łodzi publikacji „Skuteczność sztuki” pod redakcją Tomasza Załuskiego.

\section{Cytowanie:}

A. Rostkowska, O projekcie „po kapitalizmie”, „Praktyka Teoretyczna” nr 3(9)/2013, http://www.praktykateoretyczna.pl/PT_nr9_2013_Po_ kapitalizmie/01.Rostkowska.pdf (dostęp dzień miesiąc rok) 